\title{
Hyperkalemia by $\beta$-Fluoroethylacetate: A Report of 2 Cases
}

\author{
Eun Young Choi, M.D., Sung Kwang Park, M.D. and \\ Sung Kyew Kang. M.D.
}

\author{
Department of Internal Medicine. \\ Chonbuk National University Medical School \\ Choniu, Korea
}

\begin{abstract}
When acidemia occurs associated with mineral acids, there is a predictable increase in the serum $\mathrm{K}^{+}$concentration In uncomplicated cases of acidosis associated with nonmineral organic acids, the serum $\mathrm{K}^{+}$concentration usually remains within the normal range. The mechanism of this different effect if irmeral and organic acidemias on the transmembrane movement of $\mathrm{K}^{+}$remains undefined.

We observed increases of serum $K^{+}$concentration in 2 patients who ingested $\beta^{-}$ fluoroethylacetate solution for the purpose of committing suicide.
\end{abstract}

Key Words: B-fluoroethylacetate Metabolic acidosis. Hyperkalemia

\section{INTRODUCTION}

In a case of acidosis induced by the administration of a mineral acid, such as $\mathrm{HCl}$ or $\mathrm{NH}_{4} \mathrm{Cl}$. acidemia itself increases serum $\mathrm{K}^{*}$ concentration. ${ }^{1 \ldots}$ in is well known that hyperkalemia is caused by the release of intracellular $K^{+}$ into extracellular fluid. In contrast in animal experiments involving the administration of nonmineral acids, such as lactic acid ${ }^{6)}$ and methylmalonic acid $^{n}$ there was no increase in serum $\mathrm{K}^{+}$concetration by a nonmineral acid clinically except in diabetic ketoacidosis ${ }^{91}$

We report 2 cases of hyperkalemia which developed after $\beta$-fluoroethylacetate was ingested in which serum $\mathrm{K}^{+}$was increased to 5.57 meq I and $6.7 \mathrm{meq} / 1$, respectively, with severe metabolic acidosis

\section{CASE 1}

A 59-year-old woman was admitted to the hospital via the emergency room in a semicoma with vomiting and intermittent general convul-

Address repint requestr.sung $K$ KangM D heomtment of intemat Medeme Cumbuk National Unmorsty Medral School Chomu. Chontum 520 Korea sions, following the ingestion of $6.0 \mathrm{gm}$ of $\beta$. fluoroethylacetate (Kilatol $F^{R}$ ) in a suicide attempt.

She had used no medication previously. There was no history of convulsions or renal disease.

On physical examination, she was obviously semicomatose without cyanosis. The oral mucosa appeared burned. On chest examination she was found to have fine. moist rales and arrhythmia without a murmur. Neurological examination revealed decreased deep tendon reflex.

The temperature was $37 \mathrm{C}$, the pulse 92 . and the respirations $25 / \mathrm{min}$. The blood pressure was $110 / 70 \mathrm{mmHg}$.

The laboratory findings on admission were as follows: hemoglobin $13.6 \mathrm{gm} \%$, hematocrit $39.2 \%$ white cell count 10,000 . platelet count 40,200 . total protein $6.2 \mathrm{gm}$, and albumin $3.9 \mathrm{gm} \%$. Blood gas and electrolytes findings are shown in Table 1. Urinalysis disclosed $(+)$ protein and $(+)$ sugar

On admission, a Levin tube was inserted. and a gastric lavage was done. She was in metabolic acidosis $\left(\mathrm{pH} 7.26, \mathrm{HCO}_{3} 17 \mathrm{meq} / 1, \mathrm{pCO}_{2} 38\right.$ $\mathrm{mmHg}$ ). Serum $\mathrm{K}^{+}$concentration was 5.57 meq/I. Therefore, $24 \mathrm{meq} / \mathrm{l}$ of $\mathrm{HCO}_{3}$ was given every 2 hours for 24 hours along with 10\% glucose solution and $5 \%$ dextrose in saline.

Forty milligrams of Lasix was also prescribed 
every 8 hours for 24 hours. On the second hospital day the $\mathrm{pH}$ was 7.34, $\mathrm{HCO}_{3} 19 \mathrm{meq} / 1, \mathrm{pCO}_{2} 36$ $\mathrm{mmHg}$ and serum $\mathrm{K}^{+} 4.9 \mathrm{meq} / \mathrm{I}$. Bicarbonate and hypertonic glucose solution were given. On the 3rd hospital day she was in a clear mental state. Sixty milligrams of Lidocaine was given to control severe intermittent ventricular premature contraction. Prednisolone was given to relieve esophageal edema, and penicillin $G$ to prevent infection. On the 5th hospital day there was a marked improvement in the ECG, and Lidocaine was withdrawn. On the 6th hospital day the results of the laboratory examinations were $\mathrm{pH} 7.36, \mathrm{HCO}_{3}$ $24 \mathrm{meq} / \mathrm{l}, \mathrm{pCO}_{2} 43 \mathrm{mmHg}$ and serum $\mathrm{K}+3.6 \mathrm{meq}$ ? 1. She began to eat a normal diet on the 7 th day.

An esophagogram showed a mild stricture of the entire esophagus.

The patient had recovered completely after 52 days in the hospital and was discharged.

\section{CASE 2}

A 38-year-old woman brought to the emergency room with convulsions, following the ingestion of $20 \mathrm{ml}$ of $\beta$-fluoroethylacetate solution 12 hours before in a suicide attempt

She had used no medication previously. There was no history of convulsions or renal disease.

She was agitated without cyanosis. Chest examination revealed fine moist rales and arrhythmia without a murmur.

The temperature was $36.5^{\circ} \mathrm{C}$. the pulse 86 , and the respirations 24 /min. The laboratory findings on admission were as follows: hemoglobin 13.2 gm $\%$, hematocrit $37.2 \%$, white blood cell count 6 , 900 , platelet count 26,200, total protein $6.5 \mathrm{gm} \%$, and albumin $3.5 \mathrm{gm} \%$.

The BUN was $32 \mathrm{mg} \%$ and creatinine was 2.0 $\mathrm{mg} \%$. Sodium was $158 \mathrm{meq} / \mathrm{l}$ and $\mathrm{K}$ was $6.7 \mathrm{meq} /$ 1. The findings on an arterial blood gas analysis were $\mathrm{pH} 6.83, \mathrm{pCO}_{2} 90 \mathrm{mmHg}, \mathrm{HCO}_{3} 15 \mathrm{mmol} / 1$ and $\mathrm{PO}_{2} 55 \mathrm{mmHg}$ (Table 1).

Urinalysis revealed $(+)$ proteinuria. Electrocardiogram showed atrial fibrillation.

Two hours after arrival, she expired.

\section{DISCUSSION}

In acidosis associated with mineral acids, acidemia, in which there is a predictable increase in serum $\mathrm{K}^{+}$concentration occurs while in uncomplicated cases of acidosis associated with organic acids, the serum $\mathrm{K}^{+}$concentration usually remains within the normal range. This difference is thought to be caused by the difference of membrane permeabilities between mineral acid and organic acid. Normally, there exist some mechanisms to maintain the $\mathrm{H}^{+}$balances between intraceillular and extracellular fluid and some mechanisms to maintain the balanced $\mathrm{K}^{+}$ratio. The change in the $\mathrm{H}^{+}$ ratio may cause the change in serum $\mathrm{K}^{+}$concentration. Recently. Alder et al. ${ }^{101}$ reported that there may be an undetermined relationship between intra-and extracelfular $\mathrm{H}^{+} / \mathrm{K}^{+}$ratio, but the definite relationship between serum $\mathrm{pH}$ and $\mathrm{K}^{+}$concentration remains unclarified. In 1958 Tobin $^{5)}$ infused $\mathrm{HCl}, \mathrm{NH}, \mathrm{Cl}$ and acetic acid intravenously into nephrectomized cats.

Table 1. Clinical Information and Biochemical Parameters in the Plasma on Admission

\begin{tabular}{|c|c|c|}
\hline & Case 1 & Case 2 \\
\hline Age. Sex & 59. F & 38. $F$ \\
\hline Amount of $\beta$-FEA & $60 \mathrm{ml}$ & $20 \mathrm{ml}$ \\
\hline Onset to ER & 2 hours & 12hours \\
\hline Chief complaints & semicoma and convulsion & convulsion \\
\hline ECG findings & PVC & atrial fibrillation \\
\hline $\mathrm{pH}$ in arterial & 7.26 & 6.83 \\
\hline $\mathrm{pCO}_{2} \quad \mathrm{mmHg}$ & 38 & 90 \\
\hline $\mathrm{HCO}_{3}$ mmoll & 17 & 15 \\
\hline $\mathrm{Na}$ meq 1 & 130 & 158 \\
\hline K meq I & 5.57 & 6.7 \\
\hline BUN $m g \%$ & 24 & 32 \\
\hline Creatinime $m g \%$ & 1.2 & 2.0 \\
\hline Outcome & Recovered & Expired after 2 hours \\
\hline
\end{tabular}


He reported that there was a significant increase in serum $\mathrm{K}^{+}$concentration in a $\mathrm{HCl}, \mathrm{NH}_{4} \mathrm{Cl}$ group after 2 hours and no change in that of the lactic acid and acetic acid groups. In 1980 Oster et al. ${ }^{11,12}$ infused $\mathrm{HCl}, \mathrm{NH}_{4} \mathrm{Cl}$, and acetic acid into dogs. They reported an increase in serum $\mathrm{K}^{+}$ concentration in the $\mathrm{HCl}$ and $\mathrm{NH}_{4} \mathrm{Cl}$ group but a decrease in it in the initial period in the lactic acid group. Cohen et al. ${ }^{13)}$ mentioned in his review of a physiological phenomenon of lactate transport through cellular membrane, that lactic acid enters into cells in 2 forms, as ionized lactate and as unionized lactic acid. In 1983 On et al. ${ }^{(4)}$ reported the development of hyperkalemia in dogs in a severe acidosis state $\left(\mathrm{pH} 6.9, \mathrm{HCO}_{3} 6.0 \mathrm{meq} / 1\right)$ which was induced by giving lactic acid infusions. In 1984 Kang $^{151}$ induced acidosis by giving lactic acid infusions to dogs for 4 hours. He reported that the serum $\mathrm{K}^{+}$concentration decreased below the baseline for the first 2 hours, before it started increasing. He suggested that hyperkalemia might develop if severe acidosis induced by nonmineral acid were to have been prolonged further. There have been a few reports to the effect that hyperkalemia has developed in humans with organic acidosis. especially diabetic ketoacidosis or lactic acidosis

The fluoroacetate ${ }^{161}$ which the patients had taken is a highly toxic. nonmineral acid which comes from the South African Plant. Dichapetalum Cymosum. It is intended to be used as a rodentcide. The human lethal dose is $5 \mathrm{mg} / \mathrm{kg}$. When administered to living subjects it interrupts the cellular metabolic process by blocking the citric acid cycle. Fluoroacetate itself is nontoxic, but once transformed into fluorocitrate acid it is highly toxic, causing generalized convulsions and severe ventricular arrhythmia.

\section{REFERENCES}

1. Burnell JM, Villamil MF, Uyeono BT, Scribner: The effect in humans of extracellular $\mathrm{pH}$ change on the relationship between serum potassium concentration and intracellular potassium. I Clin Invest 35:935.1956
2. Elkinton JR, Singer RB, Barker ES, Clark JK: Effects in man of acute experimental respiratory alkalosis and acidosis on ionic transfers in the total body fluids. J Clin Invest 34:1671,1955

3. Giebisch G, Berger L, Pitts RF: The extrarena! response to acute acid-base disturbances of respiratory origin. J Clin Invest 34231, 1955

4. Keating RE, Weichselbaum TE, Alanis M, Margraf HW. Elman R: The movement of potassium during experimental acidosis and alkalosis in the nephrectomized dog. Surg Gyne \& Obst 96:323, 1953

5. Tobin RB: Varying role of extracellular electroIytes in metabolic acidosis and alkalosis. Am $J$ Physiol 186:131, 1956

6. Tobin RB: Varying rote of extracellular electroiytes in metabolic acidosis and alkalosis. Am J Physiol 195:686, 1958

7. Rogers TA, Wachenfeld AE: Effect of physiologic acids on electrolytes in rat diaphragm. Am $J$ Physiol 193.625. 1958

8. Perez GO, Oster JR, Vaamonde CA: Serum potassium concentration in acidemic states Nephron 27:233, 1981

9. Milfoxd. F: Serum potassium in lactic acidosis and ketoacidosis. N Engl J Med 300 1087, 1979

10. Adler S, Fralyer OS: Potassium and intracellular pH. kidney int 11:433, 1977

11. Oster JR. Perez GO, Vaamonde CA.: Relationship between blood pH and potassium and phosphorous during acute metabolic acidosis. Am I Physiol 235(4).F345, 1978

12. Oster JR, Perez GO, Castro A, Vaamonde CA Plasma polassium response to metanbolic acidosis induced by mineral and nonmineral aciós. Mineral Electro Metab 428, 1980

13. Cohen RD, lles RA: Lactic acidosis: Some physiological and clinical considerations. Clin Sci Mol Med 53.405, 1977

14. On MS, Uribarri J, Alveranga D, Kang SK, Carroll HJ: Hyperkalemia by organic acidosis (Abstracts). The Am Society of Nephrology. 16th Annual Meeting P 143A' 1983

15. Kang SK: Hyperkalemia by organic acidosis. (Abstracts). The Korean J of Nephrology 4:P149. 1985

16. Haddad LM, Winchester JF: Clinical Management of poisoning and Drug Overdose. WB Saunders Company. Philadelphia 743, 1983 